\title{
An empirical study based on BSC-DEA to measure the relative efficiencies of different health care centers in province of Semnan, Iran
}

\author{
Azam Ghotbuee $^{\mathrm{a}^{*}}$, Mohammad Hemati ${ }^{\mathrm{b}}$ and Ramezan Fateminezhad ${ }^{\mathrm{c}}$
}

${ }^{a}$ Master student of Industrial Management, Islamic Azad University, Semnan Branch, Semnan, Iran

${ }^{b}$ Department of Management, Islamic Azad University, Semnan Branch, Semnan, Iran, P.O.Box: 35145-175

${ }^{c}$ President and Master of Information Technology Center, Social Security Treatment of Semnan Province, Semnan, Iran

\begin{tabular}{|c|c|}
\hline ART I C LE I NFO & ABSTRACT \\
\hline $\begin{array}{l}\text { Article history: } \\
\text { Received March 29, } 2012 \\
\text { Received in Revised form } \\
\text { June, } 12,2012 \\
\text { Accepted } 19 \text { June } 2012 \\
\text { Available online } \\
\text { June } 282012 \\
\text { Keywords: } \\
\text { Balance score card } \\
\text { Data envelopment analysis }\end{array}$ & $\begin{array}{l}\text { In this paper, we present an empirical investigation to measure the relative efficiency of seven } \\
\text { health care centers in province of Semnan, Iran, which were under the coverage of social } \\
\text { security organization of Iran. The proposed model of this paper uses a hybrid of balanced score } \\
\text { card and data envelopment analysis for performance measurement. The proposed sudy uses } \\
\text { four perspectives of balanced score card including learning and growth, internal process, } \\
\text { customer and financial perspectives and within each perspective, data envelopment analysis is } \\
\text { adopted so that the outputs of each perspective are used as inputs of the other perspective. The } \\
\text { preliminary results indicate that all seven units perform relatively well and the overall } \\
\text { efficiency of all units in this province is } 0.769 \text {. }\end{array}$ \\
\hline
\end{tabular}

(C) 2012 Growing Science Ltd. All rights reserved.

\section{Introduction}

Performance measurement and efficiency estimation for any organization has been an interesting issue among interested researchers. The process normally concentrates on various parts of an organization plans, processes as well as human resources by necessary performance evaluation system for development and stability in today's competition field. Performance evaluation helps monitoring deviation from necessary goals and target plans. There are literally various reasons for measuring the relative efficiency in health care sector such as:

1. Control and supervision of branches which must be surveyed regarding their status utilizing appropriate standards

2. The performance of managers of health care units must be rewarded by a proper punishment and encouragement system for creating responsibility feeling.

* Corresponding author. Tel: +989192312722

E-mail addresses: ghotbuee@yahoo.com (A. Ghotbuee) 
3. Performance measurement helps set up some standards.

4. It can generate a safe competition among various units by evaluation of health care systems and determine their faults and powers.

Performance measurement has been substantially changed during the past few years. The primary objective of recent models is on growth, development and improvement of assessed capacity. That is, the new measuring systems focus at strategic implementation to determine the critical success factors (CSF) for the present and the future strategic planning. If the CSF factors can be improved, the company will implement and execute its strategy. Data envelopment analysis (DEA) is one of the most popular models used among many people in the world. Charnes et al. (1978) are believed to be the first who introduced the idea of DEA in forms of CCR model and shortly after, they presented an improved one in forms of BCC model (Banker et al., 1984). In DEA model, the performance of similar units are measure based on some common input/output factors and in case more than one single unit appears to be efficient we may used a so called supper efficiency to find the relative efficiency among the most efficient ones (Anderson, 2004).

Kaplan and Norton $(1992,1996,2001)$ are believed to be the first who introduced the idea of balanced score card (BSC) as a new technique for measuring the performance of a system. The idea of BSC is to focus on non-financial items affecting the efficiency of an organization. In the past, financial factors were only considered for performance evaluation. However, BSC developed the indices toward four outlooks of growth and learning, internal processes, customer and finance and intends to balance financial goals as the result of past performance ( past view indices) and three other indices (future view indices) (Abran \& Buglione, 2003). Aryanezhad et al. (2010) explained the relative importance of using BSC-DEA for performance measurement and used it for efficiency estimation in banking industry. Performance evaluation plays an important role in determining faults and difficulties of any organization as well as attempting to increase capabilities and improve activities. In their implementation, they used the outputs of each BSC perspective as inputs for another perspective. Azarbad et al. (2011) used BSC-DEA in their implementation and assumed that there are some uncertainties associated with all input/output parameters. Therefore, they applied fuzzy numbers to handle the uncertainties and considered the model for a real-world case study of banking industry where four major banks were possible candidates of a partnership. The results of this study disclosed some of the issues such as weakness of electronic banking, services and resource allocation as part of their infrastructure problems.

\section{The proposed model}

A comparative assessment on all health care centers, which are under prudential insurance coverage in province of Semnan, Iran using balanced score card and data envelopment analysis is the primary objective of this paper. There are three important questions associated with the proposed study of this paper, which are as follows,

1 Is it possible to develop a hybrid model based on DEA and BSC to measure the performance of different health care centers in province of Semnan, Iran?

2 What would be the relative efficiencies of different health care centers using an appropriate hybrid DEA and BSC model?

3 Is there a meaningful difference between the relative efficiencies of various units before and after adaptation of the proposed hybrid DEA and BSC?

The proposed model of this paper uses the information of seven health care centers in province of Semnan, Iran to rank different units in year 2011 using the following seven stages, 


\subsection{Stage 1: Vision, Mission and Values}

In the first stage, we create vision and mission in order to reach an appropriate and strategic plan.

\subsection{Strategic planning using strength, weakness, opportunities and threats (SWOT)}

This step helps determine strength, weakness, opportunities and threats associated with an organization. An appropriate strategic planning helps determine the right directions to achieve company's objectives.

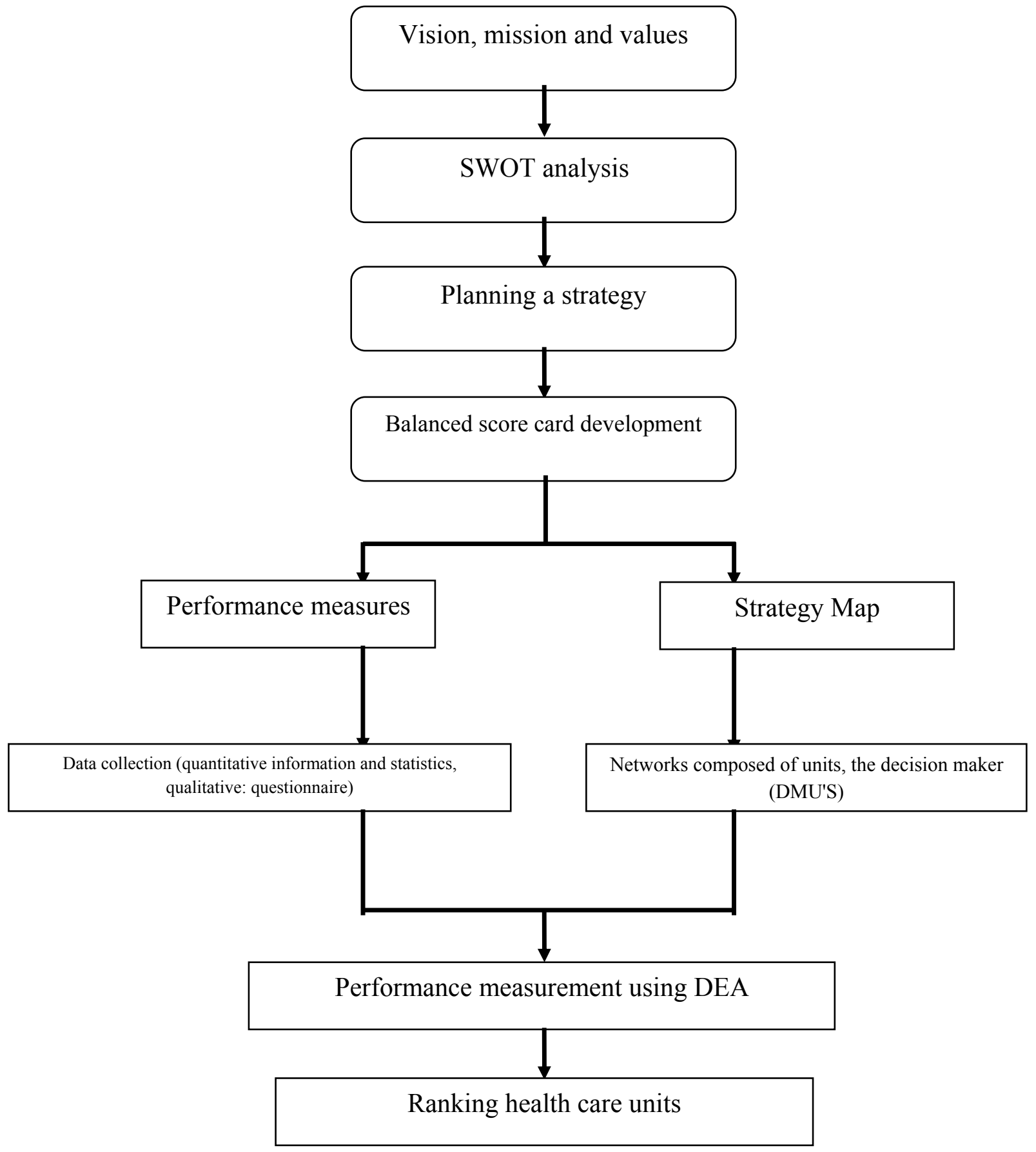

Fig. 1. Framework structure 
BSC is a management tool, used for investigating an organization in terms of four perspectives including financial, customer, internal processes and growth and learning (Chand et al., 2005). The balanced scorecard consists of four interdependent components including, 1. Strategy map that identifies and explains the strategic objectives. 2. The performance measures that show progress toward strategic goals. 3. Quantitative targets are set for each measure. 4. Selection and implementation of strategic initiatives for the quantitative performance targets to be connected. In this stage, we only need to setup strategy map and performance measures. The pioneers of BSC method believe that strategy map plays an essential role for extracting strategic keys performer objectives, which makes it possible to draw a cause and effect relationships. This map also makes it possible to implement DEA method within BSC framework. Performance measures determine short-term objectives and any organization needs to reach its long term goals through short terms objectives.

\subsection{Fourths stage: Data collection}

For the proposed plan of this paper, we have gathered the necessary information through all existing documents in social security organization of the city of Semnan, Iran. We have also performed some detailed interviews with experts and gathered all necessary information for year 2011.

\subsection{Decision making unit network}

A good network of decision makers could help find the best input/outputs of the proposed framework based on the objectives determined in strategy map.

\subsection{Selection of the best DEA technique}

Selection of the best DEA model depends on how control management team have on their decision units. There are literally various DEA methods such as constant return to scale, variable return to scale, etc. and we chose a special model explained in the next section.

\subsection{DEA implementation}

In this section, we gather the necessary data for inputs/outputs of the DEA model measure the performance of each seven units, accordingly (See Fig. 1).

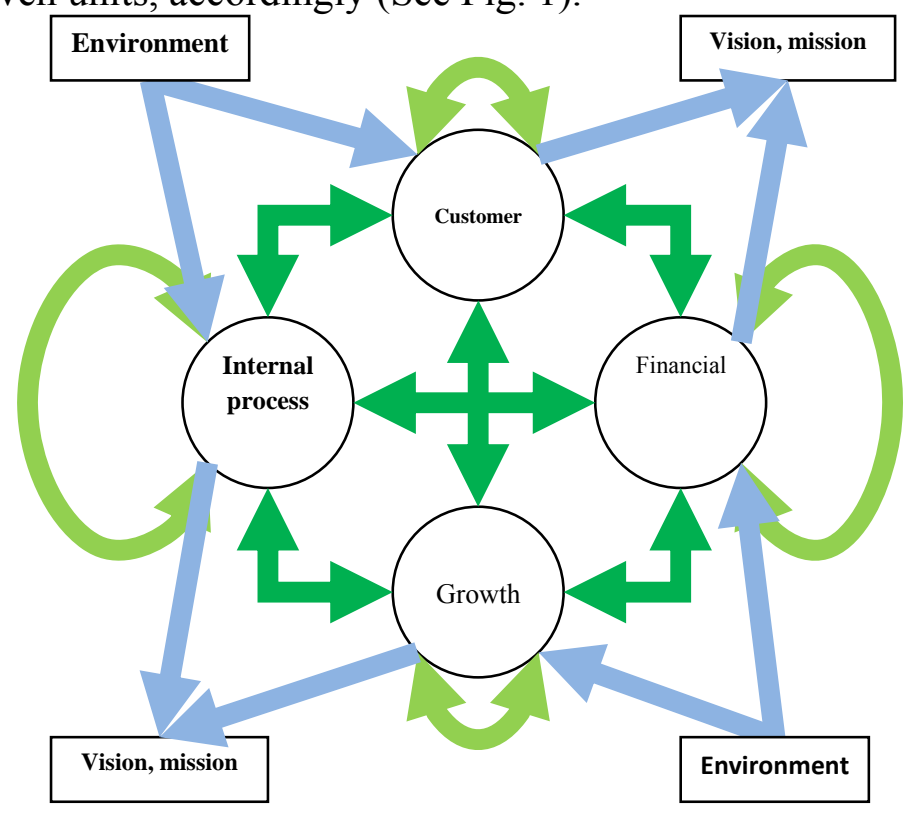

Fig. 2. Framework of BSC 


\section{The results}

In this section, we present details of the proposed model of this paper, which is applied for ranking of seven health care units. Table 1 shows strategy map in terms of four BSC perspectives.

\section{Table 1}

Different strategies in terms of BSC perspectives

\begin{tabular}{ll}
\hline BSC perspective & Strategy \\
\hline Financial & S1- Operating performance improvement \\
Customer & S2- Customer satisfaction in terms of different services \\
& S3- Developing brand by providing high quality services \\
Internal Process & S4- Developing service network \\
& S5- Productivity improvement \\
Learning and growth & S6- Acting as leading edge organization in information technology \\
& S7- Improving staff competence \\
\hline
\end{tabular}

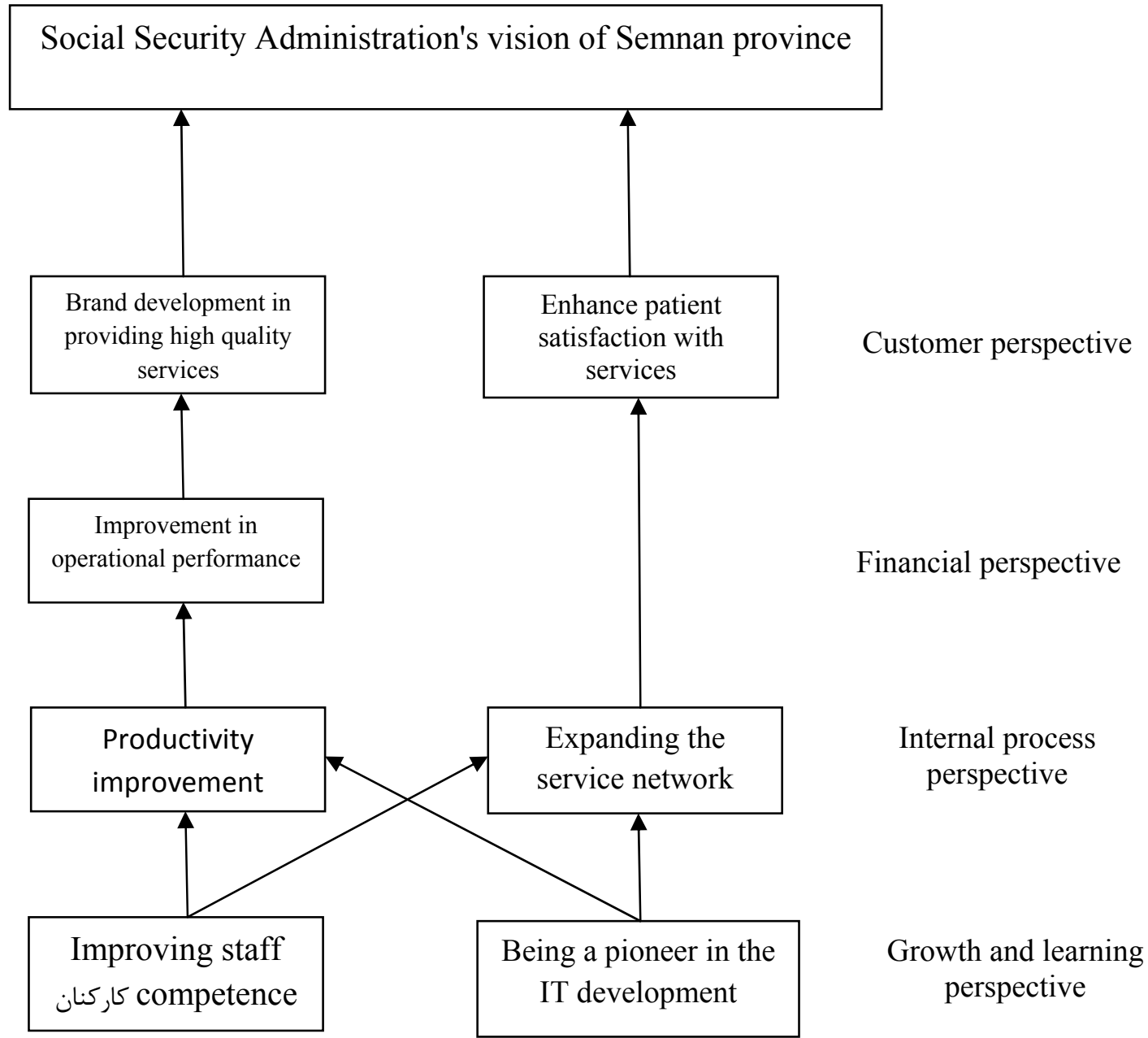

Fig. 2. Social care management strategy map Semnan

Fig. 2 shows details of the relationships among various BSC perspectives and as we can observe from the figure, the output of each perspective is considered as the input for the other perspective and this shows the cause and effect relationship among four components of the proposed framework. Table 2 shows the inputs and the outputs of the proposed DEA model used for this study. 


\section{Table 2}

Input/output of DEA model

\begin{tabular}{lll}
\hline $\begin{array}{l}\text { BSC } \\
\text { perspective }\end{array}$ & Input & Output \\
\hline $\begin{array}{l}\text { Learning } \\
\text { perspective }\end{array}$ & Environmental effects & $\begin{array}{l}\text { Training of personnel per capita } \\
\text { Information Technology development budget }\end{array}$ \\
$\begin{array}{l}\text { Internal } \\
\text { process }\end{array}$ & $\begin{array}{l}\text { Training of personnel per capita } \\
\text { Information Technology development budget }\end{array}$ & $\begin{array}{l}\text { Cost of medicines and medical equipment } \\
\text { Employment cost } \\
\text { The number of referrals during the year }\end{array}$ \\
$\begin{array}{l}\text { Financial } \\
\text { perspective }\end{array}$ & $\begin{array}{l}\text { Cost of medicines and medical equipment } \\
\text { Employment cost }\end{array}$ & $\begin{array}{l}\text { Employee productivity } \\
\text { Doctor visits in an average working hour }\end{array}$ \\
$\begin{array}{l}\text { Customer } \\
\text { perspective }\end{array}$ & $\begin{array}{l}\text { The number of referrals during the year } \\
\text { Doctor visits in an average working hour }\end{array}$ & $\begin{array}{l}\text { Service diversity } \\
\text { Patient satisfaction }\end{array}$ \\
\hline
\end{tabular}

Table 3 shows details of input/output information used for the proposed study of this paper. Note that the numbers have been normalized due to Confidentiality purpose.

\section{Table 3}

The input/output factors for the proposed DEA model

\begin{tabular}{|c|c|c|c|c|c|c|c|}
\hline & Unit 1 & Unit 2 & Unit 3 & Unit 4 & Unit 5 & Unit 6 & Unit 7 \\
\hline Employment cost & $3,653,412$ & $2,317,961$ & 774,611 & $1,155,364$ & $1,785,159$ & $2,818,182$ & 513,287 \\
\hline Medical expenses & 578,459 & 613,244 & 208,783 & 278,849 & 412,202 & 604,357 & 127,344 \\
\hline Patient satisfaction & 68.85 & 62.74 & 82 & 70.82 & 72.84 & 67.4 & 62 \\
\hline $\begin{array}{l}\text { The number of referrals } \\
\text { during the year }\end{array}$ & 44,405 & 43,325 & 13,790 & 18,548 & 29,480 & 46,883 & 9,141 \\
\hline Diversity of services & 19 & 16 & 17 & 9 & 13 & 14 & 5 \\
\hline Employee productivity & 28,091 & 39,865 & 38,731 & 37,787 & $38 \cdot 733$ & 23,813 & 31,287 \\
\hline $\begin{array}{l}\text { Average doctor visit per } \\
\text { hour }\end{array}$ & 11.56 & 10.58 & 9.01 & 10.04 & 8.13 & 9.09 & 6.44 \\
\hline IT budget & 130 & 80 & 40 & 50 & 80 & 120 & 30 \\
\hline $\begin{array}{l}\text { Training of personnel } \\
\text { per capita }\end{array}$ & 54.17 & 36.32 & 41.5 & 37.32 & 31.23 & 48.78 & 29.61 \\
\hline
\end{tabular}

We have used both popular models of CCR (Charnes et al.) and BCC (Banker et al., 1984) and since both yielded the same results, we have decided to use CCR for all out computations. Table 4 shows details of efficiencies measure by DEA for all four BSC perspectives.

\section{Table 4}

The results of the implementation of DEA method

\begin{tabular}{ccccccccc}
\hline Unit & Learning & Rank & $\begin{array}{c}\text { Internal } \\
\text { process }\end{array}$ & Rank & Financial & Rank & Customer & Rank \\
\hline 1 & 1 & 1 & 0.690 & 7 & 0.395 & 4 & 0.871 & 4 \\
2 & 0.670 & 5 & 1 & 1 & 0.362 & 6 & 0.805 & 6 \\
3 & 0.766 & 3 & 0.840 & 4 & 0.927 & 2 & 1 & 1 \\
4 & 0.689 & 4 & 0.785 & 6 & 0.710 & 3 & 0.763 & 7 \\
5 & 0.615 & 6 & 0.914 & 3 & 0.390 & 5 & 0.978 & 3 \\
6 & 0.923 & 2 & 0.805 & 5 & 0.297 & 7 & 0.816 & 5 \\
7 & 0.547 & 7 & 1 & 2 & 1 & 1 & 1 & 1 \\
\hline Mean & 0.745 & & 0.848 & & 0.583 & & 0.890 & 4 \\
\hline
\end{tabular}

Finally, Table 5 shows details of the ranking of seven units in terms of the average of efficiencies we have computed in Table 4. 
Table 4

The average ranking of different unit along with the efficiency of the province

\begin{tabular}{lcccccccc}
\hline Rank & 1 & 2 & 3 & 4 & 5 & 6 & 7 & Province \\
\hline Unit & 7 & 3 & 1 & 4 & 5 & 6 & 2 & \\
Average & 0.886 & 0.883 & 0.739 & 0.736 & 0.725 & 0.710 & 0.709 & 0.769 \\
\hline
\end{tabular}

As we can observe from the results of Table 4, unit seven and unit three represent the highest efficiencies compared with other units and unit two and six operate relatively less efficient compared with other units. However, they were mostly in close competition and none of them seems to be extremely inefficient. The whole seven units maintain an average efficiency of 0.769 , which is acceptable in this sector. However, it is always possible to improve the performance of all units by reducing the inputs and increasing the outputs and creating more efficient unit.

\section{Conclusion}

In this paper, we have presented an empirical study to measure the performance of seven health care units located in city of Semnan, Iran. The proposed model of this paper took advantage of balanced score card combined with data envelopment analysis to measure the relative efficiency of these units. The method used the outputs of each four balanced score card perspective as inputs of the other perspectives. In learning and growth stage, we environmental effects are considered as input and training of personnel per capita and information technology development budget are considered as the outputs. The internal process uses the outputs of growth stage and considered cost of medicines and medical equipment, employment cost and the number of referrals during the year as the outputs. The outputs of financial perspective included employee productivity and doctor visits in an average working hour while customer perspective used service diversity and patient satisfaction as the primary outputs of the DEA implementation within each stage of BSC method.

This paper can be extended into a more realistic survey by considering uncertainty on all input/output data and implementing robust DEA within BSC method and we leave it for interested researchers as future study.

\section{Acknowledgment}

The authors would like to thank the anonymous referees for their insight on earlier version of this paper. We are also grateful for generous support of social security organization of the province of Semnan.

\section{References}

Abran A., \& Buglione L. (2003). A multidimensional performance model for consolidating Balanced Scorecards, Advances in Engineering Software, 34, 339-349.

Aryanezhad, M.B., Najafi, E., \& Bakhshi Farkoosh, S. (2010). A BSC-DEA approach to measure the relative efficiency of service industry: A case study of banking sector. International Journal of Industrial Engineering Computations, 2(2), 273-282.

Anderson, T. (2004). Data Envelopment Analysis, Encyclopedia of Information Systems, 445-454.

Azarbad, M., Ekhtiari, M., Sarfaraz, A.H., \& Abdi, F. (2011). A framework to select commercial bank partner using fuzzy BSC-DEA method. Management Science Letters, 1(4), 467-480.

Banker, R.D., Charnes, A., \& Cooper, W.W. (1984). Some models for the estimation of technical and scale inefficiencies in Data Envelopment Analysis. Management Science, 30, 1078-1092.

Chand, D., Hachey, G., Hunton, J., Owhoso, V., \& Vasudevan, S. (2005). A balanced scorecard based framework for assessing the strategic impacts of ERP systems. Computers in Industry, 56, $558-572$. 
Charnes, A., Cooper, W. W., \& Rhodes, E. (1978). Measuring the efficiency of decision making units, European Journal of Operational Research, 6, 429-44.

Kaplan, R. S. \& Norton, D. P. (1992). The balanced scorecard - measures that drive performance, Harvard Business Review, 70(1), 71-79.

Kaplan, R.S. \& Norton, D.P. (1996). The balanced scorecard: translating strategy into action, Harvard Business School Press, Boston, MA.

Kaplan, R. S. \& Norton, D. P. (2001). The strategy-focused organization: how balanced scorecard companies thrive in the new business environment, Harvard Business School Publishing Corporation. 